Kosterlitz, H. W. (r933). Arch. exp. Path. Pharmak. 173, 159.

Kosterlitz, H. W. (I944). Nature, Lond., r54, 207.

Kosterlitz, H. W. (1947), F. Physiol. 106, 194.

Lagerstedt, S. (1947). Acta anat. 2, 392.

Lison, L. (1936). Histochimie Animale: Méthodes et Problèmes. Paris: Gauthier-Villars.

Maun, M. E., Cahill, W. M. \& Davis, R. M. (1945a). Arch. Path. (Lab. Med.), 39, 294.

Maun, M. E., Cahill, W. M. \& Davis, R. M. (r945b). Arch. Path. (Lab. Med.), 40, 173.

Maun, M. E., Cahill, W. M. \& Davis, R. M. (1946). Arch. Path. (Lab. Med.), 4r, 25.

McCoord, A. B., Clausen, S. W., Katsampes, C. P. \& Goff, B. L. (1947). Food Tech., Champaign, I, 263 .

Morgulis, S. (1923). Fasting and Undernutrition. New York: Dutton.

Palay, S. L. \& Lazarow, A. (1946). Anat. Rec. 96, 55 .

Schneider, W. C. (1946). F. biol. Chem. 165, 585 .

Schneider, W. C. (1948). F. biol. Chem. 176, 259.

Schwartz, C., Scott, E. B. \& Ferguson, R. L. (195I). Anat. Rec. rro, 3 I3.

Spector, H. \& Adamstone, F. B. (I950a). F. Nutr. 40, 213.

Spector, H. \& Adamstone, F. B. (1950b). Arch. Path. (Lab. Med.), 49, I73.

Wang, C. F., Hegsted, M., Lapi, A., Zamcheck, N. \& Black, M. B. (1949). F. Lab. clin. Med. $34,953$.

Willcock, E. G. \& Hopkins, F. G. (r9o6). F. Physiol. 35, 88.

Williams, J. N. Jr., Denton, A. E. \& Elvehjem, C. A. (1949). Proc. Soc. exp. Biol., N.Y., 72, 386.

Williams, J. N. Jr. \& Elvehjem, C. A. (1950). $¥$. biol. Chem. r83, 539.

Williams, J. N. Jr., Feigelson, P. \& Elvehjem, C. A. (1950). F. biol. Chem. 187, 597.

Williams, J. N. Jr., Feigelson, P., Shaninian, S. S. \& Elvehjem, C. J. (1951). F. biol. Chem. I89, 659.

\title{
Serum Gholesterol and the Diet in Glinically Healthy Men at Slough near London
}

\author{
BY ANCEL KEYS AND MARGARET HANEY KEYS \\ Laboratory of Physiological Hygiene, University of Minnesota School of \\ Public Health, Minneapolis, Minnesota, and Laboratory of Human \\ Nutrition, Churchill Hospital, Oxford
}

(Received 23 October 1953)

It is now clear that the diet has a major influence on the concentration of cholesterol in the blood, but that there are great differences between species. In contrast with the rabbit and the chick, controlled experiments indicate that in man the dietary intake of cholesterol itself is unimportant over the range of possible natural diets (Heymann \& Rack, I943; Messinger, Porosowska \& Steele, 1950; Moses, 1952), but that a rapid and consistent effect is brought about by changes in the total fat intake (Keys, Mickelsen, Miller \& Chapman, r950; Hildreth, Mellinkoff, Blair \& Hildreth, I951; Keys, I952; Pomeranze, Green \& Goldbloom, 1952; Keys, 1953 $a, b$ ). These observations explain the results of clinical trials with diets low in both total fats and cholesterol (e.g. Kempner, 1948; Schwartz \& Merlis, 1948; Chapman, Gibbons \& Henschel, 1950) and the absence of a relationship in surveys in the U.S.A. between cholesterol intake and serum cholesterol (Keys, 1949; Gertler, Garn \& White, I950; Wilkinson, Blecha \& Reimer, 1950).

Such experiments on man are necessarily of limited duration, and the results may be affected by previous dietary habits. The more persistent, long-range relationships between the blood cholesterol and the diet, however, can be studied with suitable 
population samples which, moreover, afford information on possible relationships of the diet and the blood cholesterol level to the incidence of diseases, notably of atherosclerosis and consequent heart disease, in which cholesterol is obviously involved.

Elsewhere (Keys, Fidanza, Scardi \& Bergami, I952; Keys, 1953 $a, b$; Keys, Vivanco, Rodriguez-Miñon, Keys \& Castro-Mendozo, 1954; Keys, Fidanza, Scardi, Bergami \& Keys, 1954), we have published recent data from Italy and Spain on populations consuming only small amounts of fats, in comparison with men in Minnesota who are habitually on a high-fat diet. This paper is to report findings in the spring of $195^{2}$ on middle-aged men in Slough near London whose diets were being studied concurrently by members of the staff of the Ministry of Health.

\section{EXPERIMENTAL}

Subjects, diets and methods. The subjects were forty-eight clinically healthy men from 40 to 55 years of age, employed in small factories at or near Slough. The complete food intake of each man consuming his customary diet was measured in detail over a period of 7 days and these data, together with a description of the methods used in measuring the food intakes, are separately reported in detail (Bransby, 1954). The chief characteristics of the men and the dietary factors of present relevance are summarized in Table $\mathrm{I}$.

Table 1. Personal and dietary characteristics of the forty-eight clinically healthy men examined at Slough

\begin{tabular}{|c|c|c|c|c|c|c|c|}
\hline & $\begin{array}{c}\text { Age } \\
\text { (years) }\end{array}$ & $\begin{array}{l}\text { Height } \\
\text { (cm) }\end{array}$ & $\begin{array}{c}\text { Weight } \\
\text { (kg) }\end{array}$ & $\begin{array}{l}\text { Weight as } \\
\text { percentage } \\
\text { of U.S.* }\end{array}$ & $\begin{array}{l}\text { Calories } \\
\text { consumed } \\
\text { (Cal./day) }\end{array}$ & $\begin{array}{l}\text { Protein } \\
\text { intake } \\
\text { (g/day) }\end{array}$ & $\begin{array}{l}\text { Percentage } \\
\text { of total } \\
\text { calories } \\
\text { as fat }\end{array}$ \\
\hline Range & $40-55$ & $149-189$ & $49-90$ & $69-129$ & $2095-4942$ & $68-154$ & $28-43$ \\
\hline Mean & 44.98 & $169 \cdot 6$ & 66.04 & 93.5 & 3427 & $107 \cdot 6$ & $35^{\circ} \cdot 40$ \\
\hline S.D. & 3.84 & $7 \cdot 7$ & $10 \cdot 44$ & II 9 & 553 & $18 \cdot 4$ & $4 \cdot 17$ \\
\hline S.E. & 0.55 & $I \cdot I$ & $1 \cdot 51$ & $x \cdot 7$ & 80 & $2 \cdot 7$ & 0.60 \\
\hline
\end{tabular}

* U.S. refers to the standard United States weight tables of the Association of Life Insurance Medical Directors and The Actuarial Society of America (I9r2).

Blood samples were drawn from an arm vein under non-basal conditions, the men being called out from work to a first-aid station or mobile laboratory van. Serum was separated and the analyses were begun within a few hours, the blood being stored at $0^{\circ}$ meanwhile.

The cholesterol method was that used previously in Minnesota, Italy and Spain (Keys, Mickelsen, Miller, Hayes \& Todd, r950) and is based on the application of the Liebermann-Burchard reagent to the chloroform solution of a Bloor extract, great care being taken to control temperature and time, and to run parallel blanks and standards with every batch. The apparatus, standards and reagents were brought from Minnesota to ensure that the conditions were as far as possible the same as in previous work. Duplicate portions of serum were analysed for each sample and the analysis was repeated on additional portions whenever the duplicates differed by as much as $20 \mathrm{mg}$ of cholesterol per $100 \mathrm{ml}$. serum. 
RESULTS

Values for height and weight of the men in Slough tended to correspond closely to the data obtained in $195^{\circ}$ on the sample of 135 Englishmen studied by Kemsley (1953) and to those obtained in 1943 on 2983 Englishmen (Kemsley, 1952). Since the mean heights were closely similar in all three series, it is enough to compare weights per unit of height to obtain a useful measure of relative obesity. For the nearest corresponding ages, the mean values were $2.15 \mathrm{lb}$./in. in $1943,2.18 \mathrm{lb}$./in. in 1950 and, for the present sample, $2 \cdot 14 \mathrm{lb}$./in.

In comparison with the Minnesota sample, and with the usual U.S. standards (Association of Life Insurance Medical Directors and the Actuarial Society of America, I912), the men in Slough tended to be thin, averaging only $93.5 \%$ of the U.S. standards for equal age and height. In comparison with the Minnesota and Italian samples, the relative body-weight of the Slough men averaged only about $91 \%$, because those

Table 2. Mean percentage of total calories provided from protein, fat and carbohydrate in the diets of the forty-eight men at Slough and of the urban working-class households included in the National Food Survey in 1943 (914I households) and in 1949 (7I 19 households) (Ministry of Food: National Food Survey Committee, I95I)

\begin{tabular}{|c|c|c|c|}
\hline \multirow[b]{2}{*}{ Source of data } & \multicolumn{3}{|c|}{ Mean distribution of calories between } \\
\hline & Protein & Fat & Carbohydrate \\
\hline National Food Survey, 1943 & $12 \cdot 9$ & $34^{\cdot} \cdot$ & $53 \cdot 0$ \\
\hline National Food Survey, 1949 & $12 \cdot 5$ & $35 \cdot 3$ & $52 \cdot 2$ \\
\hline Slough, I952 & $12 \cdot 9$ & $35^{\circ} 4$ & $52 \cdot 0$ \\
\hline
\end{tabular}

two samples were 102 and I03\%, respectively, of the U.S. standards (Keys, Fidanza, Scardi, Bergami \& Keys, I954). The variability in the relative body-weight of the Slough men was large, however, the standard deviation being $12 \cdot 7 \%$ of the mean.

In spite of low relative body-weights, the calorie intake of the Slough men averaged 3427 Cal. daily. Though employed in 'light' industry, their energy expenditure was obviously fairly high. Comparison can be made with the data on urban working-class households included by the Ministry of Food: National Food Survey Committee (195I). The energy intake of the Slough men averaged $14 \mathrm{I} \%$ of the intake per head of the 7II9 families studied in 1949 .

However, as shown in Table 2, the proportions of the total calories provided by the main groups of energy-yielding nutrients are very closely similar for the Slough men and for the households in the National Food Survey, both in 1943, the first year when fats were separately recorded, and in 1949, the latest year available to us. In several respects, then, the men of Slough may be a reasonably good English sample in matters pertaining to the diet.

The results for the serum concentration of cholesterol are analysed with respect to age in Table 3 which gives also data from Minnesota and Naples for comparison. It should be noted that, in contrast with the other groups, the men in Minnesota were studied in the basal state and therefore their cholesterol values might be slightly lower, but not more than 3 or $4 \%$ in our experience, than in the non-basal state, 
which was the condition of the men studied in England and in Italy. The data from Tanner (195I) given in Table 3 are for young Englishmen in London and are comparable with the Slough data in metabolic state and analytical method.

The Minnesotans and the Englishmen are much alike in the concentration of serum cholesterol, though the age trend might possibly be somewhat smaller in the Englishmen. The total mean increase from mean age 22 to mean age 45 is $60 \mathrm{mg} / 100 \mathrm{ml}$. in the combined English groups, and from mean age 22 to mean age 50 it is

Table 3. Serum total cholesterol concentration in the men from Slough and in healthy men of similar age in Minnesota (Keys, Mickelsen, Miller, Hayes $\sigma^{\circ}$ Todd, 1950, and this paper, $p$. 145), in Naples (Keys, Fidanza, Scardi, Bergami $\mathscr{E}^{\circ}$ Keys, 1954) and in young men in England (Tanner, 1951). The value $b$ is the increase in mean cholesterol concentration per year of age

\begin{tabular}{|c|c|c|c|c|c|c|}
\hline \multirow{2}{*}{$\begin{array}{l}\text { Origin of } \\
\text { sample }\end{array}$} & \multirow{2}{*}{$\begin{array}{c}\text { No. of } \\
\text { men }\end{array}$} & \multicolumn{2}{|c|}{$\begin{array}{c}\text { Age } \\
\text { (years) }\end{array}$} & \multicolumn{2}{|c|}{$\begin{array}{l}\text { Serum cholesterol } \\
\text { concentration } \\
\text { (mg/ } 100 \mathrm{ml} .)\end{array}$} & \multirow[b]{2}{*}{$b$} \\
\hline & & Range & Mean & Mean & S.E. & \\
\hline $\begin{array}{l}\text { Slough } \\
\text { Slough } \\
\text { Slough }\end{array}$ & $\begin{array}{l}35 \\
48 \\
26\end{array}$ & $\begin{array}{l}40-47 \\
40-55 \\
44-55\end{array}$ & $\begin{array}{l}43 \\
45 \\
48\end{array}$ & $\begin{array}{l}248 \\
250 \\
253\end{array}$ & $\begin{array}{l}6 \cdot 3 \\
5 \cdot 8 \\
8 \cdot 4\end{array}$ & $\begin{array}{l}1.09 \\
0.80 \\
1 * 10\end{array}$ \\
\hline England & 46 & $18-36$ & 22 & 190 & $4 \cdot 3$ & $I \cdot 68$ \\
\hline $\begin{array}{l}\text { Minnesota* } \\
\text { Minnesota } \\
\text { Minnesota } \\
\text { Minnesota* }\end{array}$ & $\begin{array}{r}59 \\
1047 \\
287 \\
198\end{array}$ & $\begin{array}{l}17-29 \\
17-30 \\
45-55 \\
50-61\end{array}$ & $\begin{array}{l}2 x \cdot 5 \\
22 \\
50 \\
54\end{array}$ & $\begin{array}{l}209 \\
179 \\
248 \\
280\end{array}$ & $\begin{array}{l}5 \cdot 2 \\
1 \cdot 4 \\
2 \cdot 6 \\
3 \cdot 3\end{array}$ & $\begin{array}{r}3.89 \\
2 \cdot 29 \\
I \cdot 21 \\
-0.75\end{array}$ \\
\hline $\begin{array}{l}\text { Naples } \\
\text { Naples }\end{array}$ & $\begin{array}{l}40 \\
28\end{array}$ & $\begin{array}{l}20-34 \\
40-54\end{array}$ & $\begin{array}{l}28 \\
45\end{array}$ & $\begin{array}{l}210 \\
231\end{array}$ & $\begin{array}{l}6 \cdot 1 \\
7 \cdot 5\end{array}$ & $\begin{array}{l}3.10 \\
0.09\end{array}$ \\
\hline
\end{tabular}

$69 \mathrm{mg}$ in the Minnesotans. In any event, however, both Englishmen and Minnesotans are obviously different from the Neapolitans. If the observed slopes ( $b$ in Table 3$)$ are used to extrapolate to ages in the fifties, the difference between the Englishmen and the Americans, on the one hand, and the Italians, on the other, would be of the order of $30 \mathrm{mg}$ or more in the mean cholesterol values. It is interesting that the interindividual variation is much the same in all the series, the standard deviations all being around $30-40 \mathrm{mg} / \mathrm{x} 00 \mathrm{ml}$. or about $15 \%$ of the mean.

The relationship between the serum-cholesterol concentration and the relative bodyweight was examined by correlation methods. The medico-actuarial tables of 'standard' weights (Association of Life Insurance Medical Directors and the Actuarial Society of America, 1912) were chosen as convenient bases for expressing relative body-weight, firstly, by using the tabular values for given height and given age and, secondly, by using the values for given height at age 25. The height at age 25 has been suggested in the U.S.A. to correspond to something like an 'ideal' weight. The results of the correlation and partial correlation analysis, the latter eliminating the effect of age and the former merely ignoring it, are summarized in Table 4 . None of the correlation coefficients in Table 4 is significantly different from zero $(P \simeq 0.2)$.

The last point for consideration here is the possibility of a relationship between the serum-cholesterol concentration and the percentage of total calories supplied by total 
fats in the diet. The coefficient of correlation between these two variables in the Slough series, age and relative body-weight being ignored, is $r=0.103$. When the effects of age and of relative body-weight are eliminated the result is $r$ (partial) $=0.043$. In the present material, then, there is no evidence of a relationship between serum cholesterol and the percentage of dietary calories provided in the form of fats. Such a result is perhaps to be expected, even if a basic relationship between serum cholesterol and percentage of calories from fats did exist, because the error in estimating the percentage of calories from fats for the individuals may actually approach the magnitude of the true inter-individual variation in the relative intake of fats.

\section{Table 4. Coefficients of correlation between serum cholesterol and relative body-zweight for the men at Slough}

$\begin{array}{ccc}\begin{array}{c}\text { Circumstances of } \\ \text { calculation }\end{array} & \begin{array}{c}\text { Coefficient of correlation for } \\ \text { relative body-weight }\end{array} \\ \text { Age ignored } & \text { U.S.* at age } 25 & \begin{array}{c}\text { Percentage of } \\ \text { Age eliminated }\end{array} \\ \text { Age at equal age }\end{array}$

* U.S. refers to the standard United States weight tables of the Association of Life Insurance Medical Directors and the Actuarial Society of America (rgr 2).

\section{DISCUSSION}

Because there is evidently some basic relationship between the concentration of cholesterol in the blood serum of man and the presence or development of various metabolic diseases, particularly atherosclerosis, the literature contains many reports on 'abnormal' and 'normal' cholesterol levels. However, most of the reported 'normal' values are useless for comparison here because of failure to specify age and sex or to provide the minimum requirements for proper statistical treatment or both. Moreover, for serum-cholesterol values, as for other metabolic and biochemical variables, 'normal' subjects are often merely specified as persons, usually patients, who do not obviously suffer from diseases at present known to influence cholesterol metabolism.

The foregoing strictures do not apply to the data from Minnesota or from Naples (see Table 3), and there are enough other comparable data from young men to conclude that all healthy young men, having a reasonably adequate diet, tend to present a common picture for their serum-cholesterol concentration. Further it appears that young men and young women are much alike in this respect (Keys, Mickelsen, Miller, Hayes \& Todd, I950). The mean total cholesterol concentration was $189 \mathrm{mg}$, S.D. $= \pm 34$, per roo ml. serum in seventy-two Illinois male medical students (Peeler, Hepler, Kinney, Cisler \& Jung, 1950-r) and was $186 \pm 26$ in ten men and ten women between I9 and 35 years of age in Boston, Massachusetts (Foldes \& Murphy, 1946). Consolazio \& Forbes (1946) found that the mean for twelve men in the same age range in Boston was $182 \mathrm{mg} / \mathrm{ro0} \mathrm{ml}$. All of these subjects seemed to be in really good health, and presumably subsisted, on the average, on the relatively high-fat diet customary in the United States. For thirty Danes of from 19 to 30 (av. 24) years of age, Kornerup (1950) reported an average of $195 \mathrm{mg} / \mathrm{ro0} \mathrm{ml}$; ; these healthy young men presumably 
subsisted on the common diet of Denmark which also is relatively high in fat. In a somewhat older (average age about 30 years) group of sixty healthy persons in Amsterdam, Groen (1952) found an average of about $220 \mathrm{mg}$ cholesterol/roo ml. serum while the subjects were having a diet in which $34 \%$ of the calories were provided by fats. Finally, groups of healthy men in Spain on relatively low-fat and highfat diets exhibited serum cholesterol averages of 198 and $207 \mathrm{mg}$, respectively, at average age 26 years (Keys, Vivanco, Rodriguez-Miñon, Keys \& Castro-Mendozo, 1954). In all the groups of healthy young men studied by comparable methods, therefore, a mean value of about $200 \mathrm{mg}$ cholesterol $/ 100 \mathrm{ml}$. serum, derived from casual blood sampling, would apply to subjects not in the basal state, in spite of considerable mean differences in the composition of the diet and in relative obesity, and in all groups there is a regression of cholesterol on age, of from about $I .5$ to $3.0 \mathrm{mg}$ a year, over the range from 18 to about 35 years.

At older ages, particularly in the range of from 40 to 60 years, considerably fewer detailed data are at hand about the serum cholesterol concentration in healthy men. In the rather small groups of men on low-fat diets studied in Naples and in Madrid (Keys, 1952; Keys, Fidanza, Scardi, Bergami \& Keys, 1954; Keys, Vivanco, RodriguezMiñon, Keys \& Castro-Mendozo, 1954) there was little or no tendency for the serum cholesterol to rise from the twenties into middle age. In contrast, marked increases of serum cholesterol in relation to age were evident in groups of men studied in the Netherlands (Groen, Kamminga, Reisel \& Willebrands, 1950), in Denmark (Kornerup, 1950), and in various regions of the United States (Keys, Fidanza, Scardi, Bergami \& Keys, I954), to which must now be added the present findings from Slough. It is significant that in all the areas where there is an increase with age, the diets are relatively high in fats, from 35 to $40 \%$ of the total calories being provided as fat.

There seems to be a rather widespread belief that the serum cholesterol should tend to be directly related to relative obesity, partly because of insurance companies' mortality experience with heart disease, partly because of experimental data on rabbits (Firstbrook, 1950). The present data from Slough, however, lend no support to the idea, and are in conformity with our findings in Minnesota, Italy and Spain where, at most, there was only a trivial relationship between serum cholesterol and relative obesity as judged from relative body-weight or subcutaneous-fat thickness. In young Englishmen, Tanner (I95I) found a small but significant relationship $(r=0.43)$ between serum cholesterol and the thickness of the subscapular skinfold expressed on a logarithmic scale. The factor of age was not eliminated in Tanner's analysis, so we have re-examined his original data with the method of partial correlation, age being held constant. The coefficient of (partial) correlation, age constant, between serum cholesterol and (log) subscapular skinfold thickness is then $r=0.44$ in the young Englishmen. The result, substantially identical with Tanner's, is explained by the fact that the correlation coefficient between $(\log )$ subscapular thickness and age is almost zero, $r=0.036$.

The question of a possible effect on the serum-cholesterol concentration in man of dietary cholesterol has been repeatedly raised since the first experimental demonstra- 
tions of such an effect in rabbits more than 40 years ago. The consistently negative evidence from experiments and surveys in man has been noted elsewhere (cf. e.g. Keys, $1953 b$ ), and there is no doubt that man is vastly different from both the rabbit and the chick in this regard. It may be worth while, however, to point out that comparisons of English and American populations add more evidence that the cholesterol intake in man is relatively unimportant.

National data on apparent food consumption per head at the retail level in the United Kingdom and in the U.S.A., in 1949-50, are summarized in Table 5. Both

Table 5. Consumption of cholesterol-containing foods, and the amount of cholesterol provided thereby, in the United Kingdom and in the United States from data provided by the Food and Agriculture Organization of the United Nations for 1949-50, and from surveys of households made in the U.K. in 1949 by the Ministry of Food: National Food Survey Committee (195I) and in Minnesota by the (U.S.) Department of Agriculture Food Consumption Surveys, Minneapolis-St Paul, winter, spring, fall, 1948 (U.S. Department of Agriculture: Bureau of Human Nutrition and Home Economics, 1949). The values represent the average weekly consumption per head

\begin{tabular}{|c|c|c|c|c|c|c|c|c|}
\hline & \multicolumn{8}{|c|}{ Intake per head of cholesterol-containing foods and of cholesterol, derived from } \\
\hline & \multicolumn{4}{|c|}{ National food consumption data } & \multicolumn{4}{|c|}{ Data from surveys } \\
\hline & \multicolumn{2}{|c|}{ U.K. } & \multicolumn{2}{|c|}{ U.S.A. } & \multicolumn{2}{|c|}{ U.K. } & \multicolumn{2}{|c|}{ Minnesota } \\
\hline & $\begin{array}{c}\text { Food } \\
\text { (g/week) }\end{array}$ & $\begin{array}{c}\text { Cholesterol } \\
\text { (mg/week) }\end{array}$ & $\begin{array}{c}\text { Food } \\
(\mathrm{g} / \text { week })\end{array}$ & $\begin{array}{c}\text { Cholesterol } \\
\text { (mg/week) }\end{array}$ & $\begin{array}{c}\text { Food } \\
\text { (g/week) }\end{array}$ & $\begin{array}{l}\text { Cholesterol } \\
\text { (mg/week) }\end{array}$ & $\begin{array}{c}\text { Food } \\
\text { (g/week) }\end{array}$ & $\begin{array}{l}\text { Cholesterol } \\
\text { (mg/week) }\end{array}$ \\
\hline Eggs & 210 & 1344 & $4 \circ 5$ & 2592 & 135 & 864 & 330 & 2112 \\
\hline Butter & - & - & - & - & 100 & 280 & 192 & $53^{8}$ \\
\hline Milk & 410 & 45 & 560 & 62 & $265^{*}$ & $29^{*}$ & $470^{*}$ & $52^{*}$ \\
\hline Cheese & - & - & - & - & 60 & 72 & 75 & 90 \\
\hline Fish & 520 & 364 & I30 & $9 \mathrm{I}$ & 240 & 168 & 25 & 18 \\
\hline Meat & & & & & & & & \\
\hline Meats† & 960 & 888 & 1420 & 1400 & 530 & $53 \circ$ & II 50 & I I 50 \\
\hline Bacon & - & - & - & - & 75 & 75 & 95 & 95 \\
\hline Poultry $\ddagger$ & - & - & - & - & 40 & 32 & 190 & 152 \\
\hline Total & - & $264 I$ & - & 4145 & - & 2050 & - & 4207 \\
\hline
\end{tabular}

* Fluid milk equivalent of milk, ice cream and condensed milk, but not including butter or cheese. $\uparrow$ Meats include beef, veal, lamb, mutton, pork, offal and sausage.

$\ddagger$ Poultry includes chicken, rabbits, turkey and game.

calculation of national food consumption and household food surveys, as set out in Table 5, show that the average dietary intake of cholesterol in the United States is very much higher than in the United Kingdom. For the present purpose, the values in the columns headed 'Surveys' are the most relevant because the U.K. values refer to working-class households, in which the Slough men would properly be placed, and the men studied in regard to cholesterol in Minnesota (cf. Table 3) were drawn from the same community as is represented under the heading 'Minnesota' in Table 5. Roughly, at least, it would appear that the dietary intake per head of cholesterol in Minnesota is at least twice that of working-class households in England. Further evidence on the point is provided by the findings on fifty-nine of the 287 middle-aged 
Minnesotans represented in Table 5. Careful individual food-intake studies in 1953 on the fifty-nine men by Miss Sadye Adelson and colleagues of the Bureau of Human Nutrition and Home Economics, U.S. Department of Agriculture, indicated an average intake of $747 \mathrm{mg}$. cholesterol in a daily average intake of $253^{\circ} \mathrm{Cal}$., or $299 \mathrm{mg} / 1000$ Cal. For the U.K. households the comparable value is $12 \mathrm{I} \mathrm{mg} / \mathrm{I000} \mathrm{Cal}$. There is, however, no sign of this dietary difference in the serum values (see Table 3).

While this paper was being completed the results became available of cholesterol measurements on clinically healthy men in Minnesota who were studied in the University of Minnesota Laboratory of Physiological Hygiene during the period JanuaryJuly, $\mathrm{x} 953$. The means in $\mathrm{mg} / \mathrm{roO} \mathrm{ml}$. and the standard deviations were $209^{\circ} 4 \pm 40 \cdot 3$ for fifty-nine young men, averaging $2 \mathrm{I}^{\cdot} \cdot 5$ years of age, and $280^{\circ} 5 \pm 45^{\circ} 97$ for 198 men of average age $54^{2} 2$ years (range $50-61$ ). The regression of cholesterol on age in the older group was found to be

$$
\text { cholesterol }=32 \mathrm{I}-0.75 \text { (age in years), }
$$

the apparent decrease with increasing age being not significant.

These latest cholesterol values from Minnesota, especially for the older men, are higher than would be predicted from the earlier data of Keys, Mickelsen, Miller, Hayes \& Todd (I950). It is possible that the method currently used in Minnesota and in the work in England reported here, is slightly different from that used in 1947-9 to obtain the previous values for Minnesota. This question is now under careful scrutiny but it seems that, in any case, the values obtained in Minnesota in 1953 may be more strictly comparable with the values reported here for Slough and, possibly, with the values reported by Tanner (195 I) for young men in London. The net result, then, would be to indicate that the cholesterol concentration for young men may be slightly higher in Minnesota than in London, but that for middle-aged men it is higher in Minnesota than in Slough. For age 50 the mean difference is computed to be $29 \mathrm{mg} / 100 \mathrm{ml}$., the value being derived by using the 1953 Minnesota data.

After the present paper had been submitted for publication an article appeared by Oliver \& Boyd (1953) which deserves comment. In Edinburgh, they compared 200 consecutive patients having coronary heart disease with 200 miscellaneous inpatients, matched for age and sex, and found a large average difference in serum total cholesterol. The patients with coronary disease tended to have values more than $50 \mathrm{mg} / \mathrm{r} 00 \mathrm{ml}$. higher than those for all the groups without coronary disease except women in the sixth decade. Of the individuals without coronary disease the women showed an age trend like that found in Minnesota men but the men did not exhibit this age trend. In general, all the cholesterol values for the Edinburgh patients were considerably lower than those reported in most other recent studies, including those of Groen (1952), Keys, Mickelsen, Miller, Hayes \& Todd (1950), Kornerup (1950) and Tanner (I95I). Oliver \& Boyd made no comment on the diet of their patients.

\section{SUMMARY}

I. Clinically healthy men, from 40 to 55 years old, at Slough, England, subsisting on a diet in which fats contributed an average of $35.4 \%$ of the calories were compared with men of the same age in Minnesota and in Naples, Italy, in whose diets fats 
provided about 40 and $20 \%$ of the calories, respectively. In all three groups proteins provided from 12 to $13 \%$ of total calories.

2. Compared with the Italian and American groups, the Slough men were thin but their weights corresponded closely to the data for relative body-weights from larger samples of Englishmen.

3. The mean total cholesterol concentration in the Slough men was not significantly different from that in the Minnesotans but was definitely higher than in the Neapolitans. In none of the groups of men was there any significant relationship between relative body-weight and the serum-cholesterol concentration.

4. Evidence is presented to show that the dietary intake of cholesterol of such men as those studied at Slough is about half that of men in Minnesota and that in man the serum concentration of cholesterol is unrelated to the dietary intake.

5. The data from Slough, combined with other evidence from England, the United States, Denmark, Italy and Spain, show that in healthy young men the serumcholesterol value is substantially independent of the diet but that in middle-aged men on relatively high-fat diets, as in England and the United States, the serum cholesterol concentration is significantly higher than in men on relatively low-fat diets, as in Italy and Spain.

The work reported here was aided by a research grant from the National Dairy Council, Chicago.

We are greatly indebted to Dr H. M. Sinclair of Magdalen College, Oxford, for laboratory facilities and advice, to Drs H. E. Magee and E. R. Bransby of the Ministry of Health for help in arranging for us to study the subjects and for the data on their diets, and to Drs Austin Eagger, D. Engel and Madeline Keech of the Slough Industrial Health Centre for facilities and aid with the subjects at Slough.

The senior author (A.K.) was Senior Fulbright Fellow (Research) at Magdalen College, Oxford, 195 I-2, when the laboratory work reported here was carried out.

\section{REFERENCES}

Association of Life Insurance Medical Directors and the Actuarial Society of America (1912). Medicoactuarial Mortality Investigations, Vol. I. New York: The Association of Life Insurance Medical Directors and The Actuarial Society of America.

Bransby, E. R. (1954). Brit. F. Nutr. 8, 10o.

Chapman, C. B., Gibbons, T. \& Henschel, A. (1950). New. Engl. F. Med. 243, 899.

Consolazio, F. C. \& Forbes, W. H. (1946). F. Nutr. 32, r95.

Firstbrook, J. B. (1950). Circulation, 2, 464.

Foldes, F. F. \& Murphy, A. J. (1946). Proc. Soc. exp. Biol., N.Y., 62, 2 I 5.

Gertler, M. M., Garn, S. M. \& White, P. D. (1950). Circulation, 2, 696.

Groen, J. (1952). Voeding, 13, 556.

Groen, J., Kamminga, C. E., Reisel, J. H. \& Willebrands, A. F. (r950). Ned. Tijdschr. Geneesk. $94,728$. Heymann, W. \& Rack, F. (1943). Amer. F. Dis. Child. 65, 235.

Hildreth, E. A., Mellinkoff, S. M., Blair, G. W. \& Hildreth, D. M. (I95I). Circulation, 3, 641.

Kempner, W. (1948). Amer. F. Med. 4, 545.

Kemsley, W. F. F. (1952). Ann. Eugen., Lond., 16, 3 r6.

Kemsley, W. F. F. (1953). Ann. Eugen., Lond., r8, 22.

Keys, A. (1949). Fed. Proc. 8, 523.

Keys, A. (1952). Voeding, r3, 539.

Keys, A. (1953a). Bull. Univ. Minn. Hosp. 24, 376.

Keys, A. (1953b). F. Mt Sinai Hosp, $20,118$. 
Keys, A., Fidanza, F., Scardi, V. \& Bergami, G. (1952). Lancet, 263, 209.

Keys, A., Fidanza, F., Scardi, V., Bergami, G. \& Keys, M. H. (1954). Arch. intern. Med. (In the Press.) Keys, A., Mickelsen, O., Miller, E. v. O. \& Chapman, C. B. (I950). Science, I12, 79.

Keys, A., Mickelsen, O., Miller, E. v. O., Hayes, E. R. \& Todd, R. L. (1950). F. clin. Invest. 29, 1347.

Keys, A., Vivanco, F., Rodriguez-Miñon, J. L., Keys, M. H. \& Castro-Mendozo, H. (r954). Metabolism. (In the Press.)

Kornerup, V. (1950). Arch. intern. Med. 85, 398.

Messinger, W. J., Porosowska, Y. \& Steele, J. M. (1950). Arch. intern. Med. 86, 189.

Moses, C. (1952). Amer. F. med. Sci. 224, 212.

Ministry of Food: National Food Survey Committee (1951). The Urban Working-class Household Diet 1940 to 1949. London: H.M. Stationery Office.

Oliver, M. F. \& Boyd, G. S. (1953). Brit. Heart F. 15, 387.

Peeler, A. L., Hepler, O. E., Kinney, V. M. Cisler, L. E. \& Jung, F. T. (1950-1). F. appl. Physiol. 3, 197.

Pomeranze, J., Green, M. B. \& Goldbloom, A. (1952). Bull. N.Y. Acad. Med. 28, 6II.

Schwartz, W. B. \& Merlis, J. K. (1948). F. clin. Invest. 27, 406.

Tanner, J. M. (1951). F. Physiol. 115, 371.

U.S. Department of Agriculture: Bureau of Human Nutrition and Home Economics (1949). Food Consumption Surveys, Preliminary Report, no. 9.

Wilkinson, C. F., Jr., Blecha, E. \& Reimer, A. (1950). Arch. intern. Med. 85, 389.

\title{
The Food Intake and Energy Expenditure of Gadets in Training
}

\author{
By ELSIE M. WIDDOWSON, O. G. EDHOLM ANd R. A. McCANCE \\ Medical Research Council Department of Experimental Medicine, \\ University of Cambridge, and Division of Human Physiology, \\ National Institute for Medical Research, London, N.W.3
}

(Received 4 November 1953)

If groups of adults are maintaining a steady average weight, it may be assumed that their calorie intake is meeting their requirements. Standard growth curves have been established for children and if a group of them is growing satisfactorily their nutritional requirements are probably being covered by the food provided for them. It is not, however, so easy to be sure of this at an age when growth may or may not be complete and when a gain in weight might be desirable owing to muscular development even if growth in height has ceased.

This was the problem facing those responsible for the health of a large number of young men aged $18 \frac{1}{2}-20$ years at one of the training establishments for the armed forces. The authors of this paper were consulted: they were told of the quantities and nature of the food provided by the authorities, and also the other sources from which the trainees were in the habit of obtaining additional food. On paper the 'issued' rations had a value of $3_{819} \mathrm{Cal} / \mathrm{man} / \mathrm{day}$. This seemed generous enough but it was repeatedly represented to the authors that the trainees led a most strenuous life, and that they did not appear to be gaining weight as it was thought they should. Since little was known about the energy expenditure and the food requirements of young men of this age the matter seemed one for investigation. 